\title{
Alterações curriculares de uma escola septuagenária: um estudo sobre as grades dos cursos de formação superior em Educação Física da ESEF/UFRGS
}

Alex Branco Fraga*

Felipe Wachs**

Rute Viégas Nunes**

Cibele Biehl Bossle**

Ana Paula Pagliosa Bastos***

Felipe Freddo Breunig****

\begin{abstract}
Resumo: $O$ artigo é oriundo de um estudo sobre os currículos de formação superior em Educação Física da ESEF/UFRGS em 70 anos de existência. O objetivo geral foi evidenciar elementos que mobilizaram alterações curriculares marcantes ao longo deste período. Para tanto, realizamos um mapeamento das grades curriculares de 1941 a 2010 por meio dos seguintes documentos: registros de graus, catálogos de cursos, página da UFRGS na internet entre outros. Através de análise documental destacamos seis "pontos de tensão" que se constituíram a partir de, e ao mesmo tempo mobilizaram, importantes alterações curriculares: 1) currículos da ESEF e o marco regulatório educacional 2) vinculação das disciplinas aos diferentes departamentos; 3) separação dos percursos curriculares de homens e mulheres; 4) proporcionalidade entre disciplinas obrigatórias e eletivas; 5) surgimento e expansão dos estágios obrigatórios; 6 ) fortalecimento da pesquisa na formação inicial. Por recobrir todo o período analisado, e se articular mais densamente com os demais, aqui nos concentramos exclusivamente no primeiro ponto. Concluímos que a pressão exercida pelo marco regulatório educacional sobre os cursos de formação da ESEF/UFRGS foi mais intensa em três grandes momentos: federalização da escola em 1970, mudanças curriculares de 1987 e divisão licenciatura/ bacharelado em 2005.
\end{abstract}

Palavras-Chave: Educação Física. Currículo. Formação Profissional.

\footnotetext{
'Doutor em Educação UFRGS, coordenador do POLIFES - ESEF/UFRGS. Porto Alegre, RS. Brasil

"Mestre em Ciências do Movimento Humano - ESEF/UFRGS.Porto Alegre, RS. Brasil

"'Especialista em pedagogias do corpo e da saúde - ESEF/UFRGS. Porto Alegre, RS. Brasil

"..'Aluno de Graduação em Educação Física, monitor do PET-Saúde/UFRGS. Porto Alegre, RS. Brasil
} 


\section{INTRODUÇão}

O ano de 2010 marcou os 70 anos do início das atividades da Escola de Educação Física da Universidade Federal do Rio Grande do Sul (ESEF/UFRGS). O Núcleo UFRGS da Rede CEDES ${ }^{1}$, composto por diversos grupos de pesquisa, e sob financiamento do Ministério do Esporte, desenvolveu o projeto Escola de Educação Física da Universidade Federal do Rio Grande do Sul (1940-2010): mapeando cenários da formação profissional e da produção do conhecimento em políticas públicas de esporte e lazer ${ }^{2}$, que teve por objetivo central analisar o papel da ESEF/UFRGS no desenvolvimento da Educação Física, do Esporte e do Lazer nos âmbitos local, regional e nacional. Ao grupo de estudo e de pesquisa Políticas de Formação em Educação Física e Saúde (POLIFES) coube investigar momentos significativos da história curricular dos cursos de Educação Física (EF) oferecidos pela $\mathrm{ESEF}^{3}$ ao longo deste período.

Além de ser o ano do $70^{\circ}$ aniversário, 2010 também foi o ano no qual a comunidade esefiana definiu as linhas gerais de um novo currículo para os cursos de formação superior em EF. O Conselho de Unidade da Escola de Educação Física (CONSUNI) aprovou os princípios gerais contidos em carta encaminhada pela comissão de reestruturação curricular designada pela Direção da Escola na qual indicava a necessidade de se construir um currículo unificado, que permitisse a dupla modalidade de formação (licenciatura/ bacharelado) em um curso único de EF. Assim, as possibilidades de atuação dos egressos seriam alargadas, mas sem deixar de contemplar as exigências do campo profissional contemporâneo e as diretrizes para a formação superior da área. O processo em curso, com previsão de conclusão em 2011 e implantação para os estudantes

\footnotetext{
${ }^{1}$ Os Centros de Desenvolvimento de Esporte Recreativo e de Lazer (CEDES) fazem parte de uma ação programática do Ministério do Esporte, gerenciada pela Secretaria Nacional de Desenvolvimento de Esporte e do Lazer. Reúnem instituições de ensino superior que compõem os núcleos da rede. Disponível em: <http://www.esporte.gov.br/sndel/esporteLazer/cedes/ apresentacao.jsp> Acesso em: 21 out. 2010.

2PROJETO ESEF 70 anos. Porto Alegre: UFRGS, 2010. Disponível em: <http:// www.esef.ufrgs.br/ceme/projetos/esef70anos/equipe.php> Acesso em: 19 fev. 2010.

${ }^{3} \mathrm{Já}$ que neste artigo estamos nos referindo exclusivamente à Escola de Educação Física da UFRGS, passamos a chamá-la simplesmente de ESEF.
} 
ingressantes em 2012, foi desencadeado pelos efeitos gerados no campo da formação profissional em nosso estado a partir da implantação do curso de Bacharelado em EF na ESEF em 2005, em consonância com as Diretrizes Curriculares Nacionais para os cursos de graduação em EF (FILIPPINI; DIEHL; FRIZZO, 2010). De lá para cá, as discussões em torno da divisão da formação na área em duas habilitações distintas (licenciatura e bacharelado) e as mobilizações contrárias a este modelo, a maioria delas protagonizadas pelo movimento estudantil, intensificaram-se. Um "caldo de cultura" que levou a comunidade desta escola septuagenária a investir fortemente na elaboração de mais uma profunda alteração na matriz curricular dos seus cursos de formação superior em EF.

Para quem vive intensamente o cotidiano deste processo dentro da ESEF a impressão é de que estamos diante de um dos momentos mais marcantes de sua história. Dada a intensidade dos acontecimentos, muito provavelmente as futuras investigações sobre o período haverão de confirmar tais prognósticos. Mas para tanto, é preciso destacar outros momentos singulares na trajetória curricular desta instituição longeva, muitos já não tão visíveis à comunidade esefiana contemporânea em função da "carência de estudos que reconstituam sua memória" (MAZO, 2005, p. 144).

Em Memórias da Escola Superior de Educação Física da Universidade Federal do Rio Grande do Sul (ESEF/UFRGS): um estudo do período de sua fundação até a federalização (1940-1969), Janice Mazo (2005) procura suprir parte desta carência. Mesmo não sendo o seu objetivo principal, a autora oferece uma substancial contribuição sobre os primórdios da história curricular desta que foi a primeira instituição de formação de professores de EF no Rio Grande do Sul e uma das primeiras no país. Tal fato indica não apenas a relevância da ESEF no cenário local, regional e nacional daquele tempo, mas também que as mudanças curriculares nela introduzidas afetavam de modo bastante intenso a estrutura da EF no estado. E por ter sido a única instituição formadora da área durante trinta anos (MAZO, 2005), dá para supor que qualquer alteração afetava a área de modo talvez mais intenso do que hoje. 
A intenção aqui não é avaliar o grau de importância deste ou daquele momento dos 70 anos de história curricular da ESEF. Tal empreendimento, além de desinteressante sob o ponto de vista dos estudos sobre currículo e improdutivo para a reconstituição da memória institucional, requereria limites mais largos do que os definidos para os artigos que compõem este número especial da Revista Movimento. Para dar conta da tarefa investigativa que nos coube no projeto ESEF 70 anos, julgamos mais prudente tratar de evidenciar os elementos que mobilizaram alterações curriculares marcantes nos currículos de formação superior em EF. Para tanto, optamos por trabalhar com análise documental a partir da reconstituição das grades curriculares do período que vai desde 1941, ano em foi oferecido pela primeira vez um curso de formação superior em EF na ESEF, até 2010.

A montagem do mapa das grades curriculares de 1941 a 2010 foi feita em duas etapas. Primeiramente, coletamos quase todas as grades dos últimos quarenta anos. Este período está praticamente completo nos "Catálogos de Cursos de Graduação" disponíveis na Biblioteca Central da UFRGS e nas páginas da universidade na internet. Já para remontar as grades dos períodos anteriores, foi necessário lançar mão de outras estratégias. Investimos na pesquisa sobre o material disponível no acervo do Centro de Memória do Esporte (CEME), basicamente os registros de graus, e por meio deles mapeamos as disciplinas cursadas por alunos de primeira, segunda e terceira séries de cada ano letivo.

Neste processo de mapeamento nos deparamos com uma série de fatores inusitados: nomenclaturas que soavam estranhas aos ouvidos contemporâneos; o surgimento e o desaparecimento de disciplinas em um dado período; e a ausência completa de informações sobre algumas épocas. Este último item, apesar de nossos esforços e da colaboração do pessoal técnico dos setores de registro da Universidade, resultou em um lapso de informações referentes aos anos de 1958, 1959 e entre os anos de 1963 e 1972.

É importante salientar que a reconstituição das grades funcionou como um levantamento sobre as disciplinas ofertadas no período 
analisado, que nos permitiu sistematizar a investigação sobre currículos dentro do Projeto ESEF 70 anos em seis "pontos de tensão" que se constituíram a partir de, e ao mesmo tempo mobilizaram, importantes alterações curriculares: 1) currículos da ESEF e o marco regulatório educacional; 2) vinculação das disciplinas aos diferentes departamentos; 3) separação dos percursos curriculares de homens e mulheres; 4) proporcionalidade entre disciplinas obrigatórias e eletivas; 5) surgimento e expansão dos estágios obrigatórios; 6) fortalecimento da pesquisa na formação inicial.

Resolvemos chamar nossos achados de "pontos de tensão" porque eles não apareceram como dados isolados à espera da coleta ou acontecimentos lineares prontos para serem listados, mas sim como uma trama repleta de confluências na qual nos foi possível percorrer apenas alguns de seus fios. Por recobrir todo o período analisado, e se articular mais densamente com os demais pontos de tensão, nos dedicamos neste texto a examinar exclusivamente o primeiro: relação entre o marco regulatório educacional e as mudanças estruturais mais significativas nos cursos da ESEF.

\section{UM PANORAMA DOS ESTUDOS SOBRE CURRÍCULO}

Currículo é uma palavra de uso corrente no meio educacional contemporâneo, mas é um conceito muito recente na teorização pedagógica. O Dicionário Interativo da Educação Brasileira apresenta um verbete bastante conciso sobre o termo: "conjunto de disciplinas sobre um determinado curso ou programa de ensino ou a trajetória de um indivíduo para o seu aperfeiçoamento profissional" (MENEZES; SANTOS, 2002). Zotti (2006), autora de outro verbete para o site Navegando pela História da Educação Brasileira, valese da etimologia: "o termo currículo vem da palavra latina scurrere, correr, e refere-se a curso, à carreira, a um percurso que deve ser realizado". Já para Silva (2001), currículo é uma palavra que vem do latim curriculum, e significa "pista de corrida". Buscar a etimologia da palavra é uma boa estratégia de aproximação, mas para se ter 
uma idéia dos sentidos circulantes é preciso ter uma noção sobre a produção do campo.

Apesar das controvérsias na literatura especializada sobre a origem do termo e o "nascimento" do campo (TERIGI, 1996), grande parte dos autores aponta The curriculum, livro de John Franklin Bobbitt, publicado em 1918 nos Estados Unidos, como o precursor dos estudos exclusivamente dedicados ao tema (SACRISTÁN, 1998, SILVA, 2001, MOREIRA, 2002).

Em um livro publicado originalmente em 1991, o espanhol José Gimeno Sacristán (1998) faz uma análise panorâmica sobre o termo na literatura especializada norte-americana a partir, basicamente, da tese de doutorado de Rule ${ }^{4}$ (1973) e da obra de Schubert ${ }^{5}$ (1986). O primeiro autor citado por Sacristán indica dois grupos de significado nas obras analisadas: 1) "currículo como guia da experiência que o aluno obtém na escola [...] 2) como definição de conteúdos para educação, como planos ou programas, especificação de objetivos" (SACRISTÁN, 1998, p. 14). O segundo autor citado por Sacristán apresenta "imagens" sobre currículo que povoam o pensamento especializado, dentre elas: "conjunto de conhecimentos ou matérias a serem superadas pelo aluno [...] programa de atividades planejadas, devidamente sequencializadas, ordenadas metodologicamente [...] como tarefa e habilidades a serem dominadas - como é o caso da formação profissional" (SACRISTÁN,1998, p. 14).

Em âmbito brasileiro, uma importante revisão foi realizada no livro eletrônico Sentidos de currículo: entre linhas teóricas, metodológicas e experiências investigativas (OLIVEIRA; AMORIM, 2006), uma reunião de textos encomendados pela coordenação do Grupo de Trabalho (GT) Currículo da Associação Nacional de PósGraduação e Pesquisa em Educação (ANPED) para sua $28^{a}$ Reunião anual, realizada em 2005. Ali a pluralidade de referenciais teóricos, estratégias metodológicas e empreendimentos analíticos

${ }^{4} \mathrm{RULE}$, I. A philosophical inquiry into the meaning(s) of 'curriculum'. New York University, 1973.

${ }^{5}$ SCHUBERT, W. Curriculum: Perspective, paradigm and possibility. New York. Macmillan, Pub. Comp., 1986. 
evidenciaram a polissemia do termo currículo no "estado da arte" contemporâneo, algo também detectado em um artigo de revisão de Antônio Flávio Moreira (2002), sobre os trabalhos apresentados no mesmo GT entre os anos de 1996 e 2000.

Para Flávia Terigi (1996), o alargamento do conceito de currículo verificado na literatura específica nos leva a crer que tudo o que se faz em educação é currículo. Mais adiante ela afirma que "os analistas coincidem em descrever o campo em situação de 'explosão', no sentido que se chegou a um estado no qual tudo o que acontece na instituição escolar e no sistema educativo é, de maneira indiferenciada, curriculum" (TERIGI, 1996, p. 161). Tal dispersão está intimamente relacionada às concepções teóricas subjacentes à produção curricular. De acordo com Tomaz Tadeu da Silva, quatro são as visões dominantes na teorização sobre currículo:

1) a tradicional, humanista, baseada numa concepção conservadora da cultura (fixa, estável, herdada) e do conhecimento (como fato, como informação) [...] 2) a tecnicista, em muitos aspectos similar à tradicional, mas enfatizando as dimensões instrumentais, utilitária e econômica da educação; 3) a crítica, de orientação neomarxista, baseada numa análise da escola e da educação como instituições para a reprodução das estruturas de classe das sociedades capitalistas [...] 4) a pós-estruturalista, que retoma e reformula algumas das análises da tradição crítica neomarxista, enfatizando o currículo como prática cultural e como prática de significação (SILVA, 1999, p. 12-13).

Ao mesmo tempo em que a "explosão" da produção curricular dos últimos anos ampliou o alcance da teorização especializada sobre o assunto, também contribuiu para o surgimento de nichos de estudos como, por exemplo, os que tratam dos currículos de formação profissional de uma aérea específica. No caso da EF, tal nicho emerge no final dos anos 1980, muito em função dos efeitos gerados pelos atos normativos educacionais que mudaram o panorama da formação profissional da área em 1987, e ganhou mais força no início dos anos 2000, quando as novas diretrizes curriculares para os 
cursos de graduação em EF e para formação de professores de Educação Básica ${ }^{6}$ acirraram os ânimos das discussões em torno da habilitação profissional e das possibilidades de atuação no mercado de trabalho.

\section{Estudos Sobre Currículo em Educação Física}

Os cursos de formação profissional em EF no Brasil remontam às "primeiras décadas do século XX em cursos de curta duração voltados prioritariamente para a formação dos militares" (BENITES; SOUZA NETO; HUNGER, 2008, p. 346). Podemos supor que já naquela época a área se via às voltas com uma questão curricular básica: "o que" os alunos deveriam aprender para se tornarem instrutores/professores. Apesar de haver, desde então, preocupação com o desenvolvimento de currículos, as investigações sobre "como são feitos" e "o que faziam (e fazem)" os currículos são muito recentes na área de EF.

Para termos uma idéia da produção em EF sobre este tema, fizemos uma busca em bases de dados eletrônicas de periódicos nacionais da área7 : Movimento, Revista Brasileira de Ciências do Esporte (RBCE), Motriz, Pensar a Prática, Revista da Educação Física da UEM e Revista Brasileira de Educação Física e Esporte (RBEFE). Além destas, analisamos também a base de dados do Scientific Eletronic Library Online ${ }^{8}$ (SciELO).

Esse levantamento revelou estudos com enfoques diversos sobre o tema currículo e a utilização de diferentes caminhos metodológicos: análise documental, análise de conteúdo, revisão bibliográfica, depoimento oral, cartografia, entrevista estruturada e

\footnotetext{
${ }^{6}$ Disponível em: <http://portal.mec.gov.br/index.php?option=com_content\&view= article\&id=12991 >. Acesso em: $18 \mathrm{dez} .2010$.

${ }^{7} \mathrm{~A}$ busca nestas revistas foi realizada utilizando o descritor "currículo" nos campos "assunto" ou "termos indexados" ou "pesquisa geral", de acordo com as características de cada base de dados. Os critérios de escolha das revistas foram os seguintes: classificação no Qualis Capes da Educação Física; escopo abrangendo a área pedagógica; e tradição na EF.

${ }^{8} \mathrm{Na}$ base de dados do SciELO utilizamos o descritor "currículo" e refinamos com o descritor "educação física". Escolhemos esta base de dados porque ela reúne um grande número de revistas bem ranqueadas no Qualis Capes na área da Educação.
} 
semi-estruturada, narrativa entre outros. Alguns tratam de analisar os currículos de escolas de ensino fundamental, mas a maioria se detém a analisar o ensino superior em EF, as diretrizes curriculares para os cursos de graduação, as modificações curriculares de determinados cursos, a avaliação da formação acadêmica, o perfil do profissional de EF.

Dentro deste recorte revisional, encontramos $25 \operatorname{artigos}^{9}$ que lidam com temas curriculares relativos à formação superior em EF. Destes, poucos examinam os atos normativos educacionais que produziram (e ao mesmo tempo refletiram) importantes alterações no modo de conceber e de se fazer os currículos para a formação superior em EF. Na Revista de Educação Física da UEM, destacamos dois ${ }^{10}$ : Análise crítica do currículo das disciplinas práticas do curso de educação física da Universidade Estadual de Maringá, no qual Amauri Bássoli de Oliveira (1989) trata de analisar as concepções de educação, esporte e aula resultantes da experiência adquirida pelos alunos em disciplinas de cunho prático do currículo do curso de EF da UEM; e Análise dos currículos de Ed. Física no Brasil: contribuições ao debate no qual Celi Taffarel (1992), tece uma análise panorâmica das discussões sobre currículo em EF nos três níveis de ensino previstos à época $\left(1^{\circ}, 2^{\circ}\right.$ e $3^{\circ}$ graus $)$, e analisa as possibilidades de intervenção do movimento estudantil em questões de cunho curricular.

Na RBCE dois artigos estão intimamente conectados com esta temática: Memória do currículo de formação profissional em educação física no Brasil (AZEVEDO; MALINA, 2004), que trata das continuidades e descontinuidades nas modificações curriculares ocorridas em 1969 e 1987 no curso de graduação em EF, a partir da criação da Escola Nacional de Educação Física e Desportos no Rio de Janeiro; e A formação do profissional de educação física no Brasil: uma história sob a perspectiva da legislação federal no século XX

${ }^{9}$ Não foi encontrado nenhum artigo na base de dados da Revista Brasileira de Educação Física e Esporte a partir do uso do descritor "currículo".

${ }^{10}$ Os artigos de Amauri Bássoli de Oliveira (1989) e Celi Taffarel (1992) não estão disponíveis na íntegra no endereço eletrônico da Revista de Educação Física da UEM, lá se encontram apenas o resumo de cada um. Estes artigos foram consultados na íntegra em versão impressa. 
(SOUZA NETO et al., 2004), no qual os autores procuraram identificar aspectos que contribuíram para a constituição do campo de atuação da EF no Brasil no século XX, bem como as alterações no marco regulatório educacional entre os anos de 1939 e 1987.

Na Revista Motriz dois artigos se destacam. Um é Educação Física na UNESP de Rio Claro: Bacharelado e Licenciatura (BARROS, 1995), que discute a repercussão da Resolução n. 03/ 1987 do Conselho Federal de Educação (CFE), referente à reestruturação dos cursos de graduação em EF e defende a divisão bacharelado/licenciatura, tal como foram implantadas na UNESP à época, como a melhor forma de dar conta da gradativa ampliação do campo profissional fora da escola. E o outro artigo é Teoria da Formação e Avaliação no currículo de Educação Física (FUZII, SOUZA NETO, BENITES, 2009), que também analisa os currículos de EF da UNESP, mas se concentra nas alterações do curso de licenciatura, decorrentes da implantação das diretrizes curriculares para os cursos de graduação em EF e para a formação de professores de Educação Básica entre os anos de 2002 e 2004.

A Revista Movimento, provavelmente em função do maior número de artigos publicados com esta temática, apresenta maior diversidade de enfoques. Entre os artigos encontrados nesta revista destacamos: Currículo, formação profissional na educação física \& esporte e campos de trabalho em expansão: antagonismos e contradições da prática social, de Celi Taffarel (1997), pois trata de evidenciar os vínculos entre os projetos curriculares em EF no Brasil e o projeto histórico capitalista, e de apresentar estratégias para reformulação do currículo de formação profissional na perspectiva materialista dialética; A evolução dos esportes de combate no currículo do Curso de Educação Física da UFRGS, de Rodrigo Trusz e Alexandre Nunes (2007), que recupera informações acerca da inclusão e evolução das disciplinas de combate na graduação em EF da ESEF.

$\mathrm{Na}$ base de dados SciELO, encontramos o artigo Caracterização dos currículos de formação profissional em Educação 
Física: um enfoque sobre saúde (BRUGNEROTTO; SIMÕES, 2009), no qual os autores analisam o conceito de saúde dos projetos pedagógicos de 12 cursos de EF (seis bacharelados e seis licenciaturas) de seis universidades públicas do Estado do Paraná e os relacionam com as concepções teóricas presentes nas diretrizes nacionais para os cursos de graduação em saúde.

Em que pese a diversidade temática, é curioso observar que os trabalhos publicados neste conjunto de revistas científicas da $\mathrm{EF}$ não dialogam com a literatura específica sobre currículo produzida pela área ${ }^{11}$, muitas vezes nem mesmo dentro da própria revista nas quais estão publicados, o que denota a pouca valorização do trabalho de revisão sistemática por parte dos autores. Além disso, o uso do termo currículo é bastante "livre", muito em função da diversidade de referenciais teóricos e estratégias metodológicas, mas também devido a pouca conexão analítica com obras do campo especializado dos estudos sobre currículo.

Por estarmos interessados de modo bem pontual na história curricular da ESEF, buscamos nas mesmas revistas científicas já citadas anteriormente, e na base de dados SciELO, artigos que tratassem mais especificamente da $\mathrm{ESEF}^{12}$ e localizamos 12 . Deste conjunto, três artigos publicados na Revista Movimento (GOELLNER et. al. 2005, MAZO, 2005, NUNES; MOLINA NETO, 2005) tratam de questões indiretamente ligadas ao currículo dos cursos superiores de EF, e somente um, publicado em 2006 na Revista Pensar a Prática, está diretamente ligado ao currículo da ESEF: "Alinhamento astral": o estágio docente na formação do licenciado em educação física na ESEF/UFRGS, de Rute Nunes e Alex Fraga.

É importante ressaltar que uma revisão de literatura em bases de dados nos permite transitar pela discussão, localizar marcos teórico-metodológicos e perceber como os autores se posicionam sobre o tema em fontes consideradas confiáveis, mas por mais ampla

\footnotetext{
${ }^{11}$ Esta falta de conexão com o campo especializado de estudos sobre currículo foi identificada por Claudio Lúcio Mendes em artigo de revisão (MENDES, 2005).

${ }^{12}$ Para esta nova busca utilizamos o termo "Escola de Educação Física" e depois "ESEF/ UFRGS".
} 
que venha a ser, não recobre tudo o que já foi produzido. Há uma gama de materiais disponíveis em revistas não indexadas em bases de dados, além daqueles que só constam no formato impresso, que não são visíveis à revisão de literatura eletrônica. Em função disto, recorremos a outros mecanismos de busca para tentar encontrar textos que pudessem ser importantes para o estudo que fizemos. Entre tantos artigos encontrados, cabe destacar dois de revisão que nos ajudaram a mapear as relações no campo da produção do currículo: O campo do currículo e a produção curricular na educação física nos anos 90, de Claudio Lúcio Mendes (2005), publicado na Revisa Arquivos em Movimento; e A Revista Brasileira de Ciências do Esporte e a formação profissional em Educação Física, de Francisco Souza em co-autoria com Samuel de Souza Neto (2005), publicado na Revista Digital EF Deportes.

Tanto a revisão de literatura sobre a discussão de currículo de formação profissional na EF brasileira, quanto a revisão mais pontual dos artigos que tratam direta ou indiretamente sobre os currículos da ESEF nos permitiram situar o objeto de pesquisa no contexto das discussões dos estudos sobre currículo e, então, a movimentar as análises sobre os momentos nos quais o marco regulatório educacional demandou mudanças estruturais mais significativas nos cursos da ESEF.

\section{CuRrículos da ESEF E o MARCO REGULATÓRIO EDUCACIONAL}

Em meio ao processo de recomposição das grades, e alicerçados na revisão de literatura, nos foi possível vislumbrar a força de atos normativos específicos nas principais alterações curriculares ocorridas na ESEF nos últimos 70 anos. Em função desta evidência inicial, procuramos examinar descontinuidades e/ou rupturas percebidas no conjunto das grades curriculares 
reconstituídas em correlação ao marco regulatório educacional de períodos considerados marcantes ${ }^{13}$.

A ESEF inicia suas atividades em 1940. Foi criada pelo Departamento Estadual de Educação Física (DEEF), órgão técnico subordinado à Secretaria de Educação do Estado do Rio Grande do Sul que gerenciou a escola em seus primeiros 30 anos (MAZO, 2005, GOELLNER et. al., 2005). Foi federalizada por meio do Decreto-Lei n. 62.997/1968, e efetivamente incorporada à UFRGS em 1970. Sua criação está fortemente ligada à obrigatoriedade da EF prevista na Constituição de $1937^{14}$ e ao Decreto-Lei n. 1.212/ 1939 que determinou, a partir do primeiro dia de janeiro de 1941, a exigência do diploma de licenciado em EF para desempenhar o cargo de professor desta disciplina em estabelecimentos oficiais. Previa também, para o ensino primário, a exigência do diploma de normalista especializado em EF em cidades com mais de 50 mil habitantes. Esse Decreto-Lei orientou e normatizou a criação da ESEF e dos cursos por ela oferecidos.

O primeiro curso oferecido na $\mathrm{ESEF}^{15}$ foi o Curso Normal de Educação Física em $1940^{16}$. No ano seguinte, outros quatro vieram a se somar ao precursor: Curso Superior de Educação Física; Curso de Técnica Desportiva; Curso de Treinamento e Massagem; Curso de Medicina da Educação Física e Desportos. Os cinco cursos

\footnotetext{
${ }^{13}$ Souza Neto et al (2004) discutem as implicações para a educação física dos Decretos-Lei n. 1212/1939 e n. 8270/1945 e as Resoluções n. 69/1969 e n. 3/1987 em seu artigo "A formação do profissional de educação física no Brasil: uma história sob a perspectiva da legislação federal no século XX". Este artigo nos foi bastante útil para analisar este período, mas além destas resoluções, também analisamos a Resolução $n$. 7/2004 do CNE, que se refere às diretrizes curriculares para os cursos de graduação em EF, e as Resoluções n. 1 e n. 2/2002 do CNE, que instituíram as diretrizes curriculares para a formação de professores da escola básica.

${ }^{14} \mathrm{~A}$ Constituição de 1937 determinava em seu artigo 131 que "a educação física, o ensino cívico e o de trabalhos manuais serão obrigatórios em todas as escolas primárias, normais e secundárias, não podendo nenhuma escola de qualquer desses graus ser autorizada ou reconhecida sem que satisfaça aquela exigência" (BRASIL, 1937).

${ }^{15} \mathrm{~A}$ autorização oficial para o funcionamento da Escola é concedida por meio do Decreto $\mathrm{n}$. 7.219/1941, de 27 de maio de 1941 e, em 16 de maio de 1944, o Decreto n. 15.582/1944 confere reconhecimento à Escola (MAZO, 2005).

${ }^{16}$ A Lei n. 1.153/1950, de 04 de julho de 1950, estende a alunos do Curso Normal de Educação Física, diplomados até 1942, regalias conferidas aos licenciados em EF. No período anterior a 1940, o conteúdo relacionado à EF era ministrado pelas professoras de magistério como pode ser verificado em mais detalhes no artigo desta revista (MAZO, 2005).
} 
estavam previstos no Decreto-Lei n. 1212/1939, que estipulava requisitos de ingresso e conferiam habilitações conforme o quadro abaixo:

\begin{tabular}{|c|c|c|}
\hline CURSO & REQUISITO & DIPLOMA \\
\hline Curso superior de EF & $\begin{array}{c}\text { Certificado de conclusão do } \\
\text { curso secundário fundamental }\end{array}$ & Licenciado em EF \\
\hline Curso normal de EF & Diploma de normalista & $\begin{array}{c}\text { Normalista } \\
\text { especializado em EF }\end{array}$ \\
\hline $\begin{array}{c}\text { Curso de técnica } \\
\text { desportiva }\end{array}$ & $\begin{array}{c}\text { Certificado de conclusão do } \\
\text { curso secundário fundamental }\end{array}$ & Técnico desportivo \\
\hline $\begin{array}{c}\text { Curso de treinamento } \\
\text { e massagem }\end{array}$ & $\begin{array}{c}\text { Certificado de conclusão do } \\
\text { curso secundário fundamental }\end{array}$ & $\begin{array}{c}\text { Treinador e massagista } \\
\text { desportivo }\end{array}$ \\
\hline $\begin{array}{c}\text { Curso de medicina } \\
\text { da EF e dos desportos }\end{array}$ & Diploma de médico & $\begin{array}{c}\text { Médico especializado } \\
\text { em EF e desportos }\end{array}$ \\
\hline
\end{tabular}

Quadro 1 - Requisitos de Ingresso e Habilitações

Ao longo dos anos, vários cursos foram oferecidos na ESEF: Instrutor de Educação Física Militar, Recreação, Mestre D'Armas, Ginástica Rítmica e Danças entre outros (GUTIERREZ, 1971). Atualmente, a escola também abriga os cursos de bacharelado em Fisioterapia e licenciatura em Dança; os cursos de extensão, os de especialização lato sensu e os de mestrado/doutorado no Programa de Pós-Graduação em Ciências do Movimento Humano (PPGCMH), além, evidentemente, dos cursos de graduação em EF, sobre os quais concentramos as análises nesta seção.

O primeiro curso de formação superior em EF da ESEF se estruturou a partir dos pressupostos teóricos e da lógica organizacional médico-militar, como os demais cursos de EF criados no início do século XX no Brasil. O corpo docente escalado para as disciplinas do primeiro curso superior da ESEF em 1941 era composto majoritariamente por médicos, médicos militares ou instrutores

\footnotetext{
${ }^{17}$ Para os dois primeiros anos não havia mais a exigência de curso secundário para o curso de técnica desportiva e treinamento, assim como o de massagem, para aqueles que comprovassem já estarem exercendo as funções. Lógica similar à aplicada pelo Conselho Federal de Educação Física para aqueles que trabalhavam na área antes da regulamentação da profissão em 1998.
} 
militares (BRAUNER, 1999, MAZO, 2005). O curso tinha duração total de dois anos, distribuído em duas séries letivas, com predomínio de disciplinas de instrumentalização prática. É interessante observar que algumas destas disciplinas, mesmo com ligeiras alterações de nomenclatura e da reorganização de conteúdos, ainda hoje compõem os currículos dos cursos de EF da ESEF.

O Decreto-Lei n. 1212/1939 e o Decreto-Lei n. 8270/1945, diferentemente das resoluções que os sucederam, apresentavam a particularidade de determinarem as disciplinas que deveriam ser oferecidas nas grades curriculares dos cursos de EF. Apesar de especificarem a duração do período letivo, e de exigirem dos alunos frequiência mínima, neles não estava estipulada a carga horária total que um curso deveria ter. A principal diferença entre o Decreto-Lei n. $1212 / 1939$ e o Decreto-Lei n. $8270 / 1945^{18}$, em relação ao curso superior em EF, é o acréscimo de um ano letivo. Apesar de o terceiro ano ter sido determinado pelo Decreto-Lei n. 8270/1945, verificamos que ele só veio a se efetivar de fato na ESEF na década de 1960. A inclusão de mais um ano/série, no entanto, não produziu alterações significativas na lista das disciplinas que já compunham o currículo.

Destacamos, ainda, dois aspectos no Decreto-Lei n. 1212/1939 relacionados à composição das grades. $\mathrm{O}$ primeiro é a determinação de percursos curriculares diferenciados para homens e para mulheres ${ }^{19}$; o segundo é a classificação das disciplinas em três modalidades de ensino: teóricas, exercícios e práticas. É no artigo $25^{\circ}$ deste decreto que tal ordenamento se evidencia: "a organização da educação física e dos desportos e a história da educação física e dos desportos serão dadas em aulas teóricas; a ginástica rítmica, a educação física geral e os desportos, em exercícios, e as demais disciplinas, em aulas teóricas e em aulas práticas" (BRASIL, 1939). Esta redação, além de indicar que o binarismo teoria/prática remonta aos primórdios da formação superior em EF, indica também uma

\footnotetext{
${ }^{18}$ Pelo Decreto-Lei n. 8270/1945, o curso normal passa a se chamar educação física infantil (Art. $4^{\circ}$ ) e o curso de técnica desportiva passa a exigir diploma de licenciado em educação física (Art. 21ํ) (BRASIL, 1945).

${ }^{19}$ Este foi um dos seis pontos de tensão prospectados em nossa pesquisa empírica documental, mas não será abordado neste artigo.
} 
diferenciação de sentido entre os termos "prática" e "exercício", algo de certo modo indistinguível no cotidiano das aulas da EF contemporânea.

Dois acontecimentos ocorridos nos anos de 1969 e 1970 impulsionaram grandes transformações na estrutura da ESEF, repercutindo significativamente nas grades curriculares dos cursos de EF: 1) definição do currículo mínimo em decorrência da Reforma Universitária de $1968^{20}$; e 2) federalização da Escola.

Na esteira da Reforma Universitária de 1968, o CFE expediu a Resolução n. 69/1969²1 que, baseada no Parecer n. 894/1969, fixava o currículo mínimo para EF, agrupando as disciplinas em três conjuntos: matérias de fundamento biológico, matérias didáticas e matérias gimnico-desportivas. Apesar de a Lei de Diretrizes e Bases da Educação de 1961 (Lei n. 4024/1961) evidenciar a importância de se investir em uma formação de professores mais sustentada pedagogicamente, o Parecer n. 894/1969 fazia referência ao baixo número de técnicos desportivos para atender as demandas de um campo em expansão para além dos muros da escola (BENITES; SOUZA NETO; HUNGER, 2008). O referido parecer indicava a incorporação da habilitação de "técnico desportivo" à de "licenciado em EF" como forma de incentivar a formação do primeiro. A recomendação de incorporação foi atendida na Resolução n. 69/ 1969, e exigia que os cursos implantassem o mecanismo de escolha de duas disciplinas por parte dos alunos da lista de desportos oferecida pela instituição, deixando a cargo de cada uma delas os desportos a serem listados.

A Resolução n. 69/1969, assim como os Decretos-Lei n. 1212/ 1939 e n. 8270/1945, determinava um rol de disciplinas mínimas, mas

\footnotetext{
${ }^{20}$ De acordo com Rothen (2008), a "Lei n. 5.540/1968 [Reforma Universitária] é, por um lado, fruto das discussões que se realizavam sobre o modelo de universidade a ser adotado no país, discussões que nortearam a ação do CFE na fase jurisprudencial, como na elaboração dos Decretos-Lei n. 53/1966 e n. 252/1967, por outro, fruto da vontade dos militares, mediante uma legislação centralizadora, de imporem à sociedade civil um consenso sobre o modelo de universidade e diminuírem as resistências internas das universidades ao regime militar" ( $p$. 471).

${ }^{21}$ Apesar de a literatura e de a Resolução n. 3/1987 do CFE fazerem referência à Resolução $n$. 69/1969, encontramos a mesma normatização sob a designação "Resolução n. 12 do CFE, de 05 de fevereiro de 1970" (GUTIERREZ, 1971).
} 
abria margem para que as Instituições de Ensino Superior (IES) pudessem complementar a grade de acordo com as peculiaridades locais. O currículo mínimo de um curso superior de EF prescrito nesta resolução previa o seguinte grupamento disciplinar: 1) "matérias básicas": Biologia, Anatomia, Fisiologia, Cinesiologia, Biometria e Higiene; 2) "matérias profissionais": Socorros Urgentes, Ginástica, Rítmica, Natação, Atletismo, Recreação e matérias pedagógicas. A carga horária foi estipulada em 1800 horas-aula para o curso superior em EF, com duração mínima de três anos e máxima de cinco (BRASIL, 1969a).

As matérias pedagógicas haviam sido especificadas no Parecer CFE n. 672/1969, enquanto que a Resolução n. 9/1969 apontava a imprescindibilidade das matérias de Psicologia da Educação; Didática; e Estrutura e Funcionamento do Ensino do $2^{\circ}$ grau para o exercício do magistério em escolas de $2^{\circ}$ grau (BRASIL, 1969d). Em observação a este marco legal, tais disciplinas foram agregadas à grade curricular da ESEF, fazendo com que os conhecimentos de cunho escolar se tornassem visíveis na grade curricular daquele período.

De um modo geral, podemos dizer que a incorporação da habilitação de técnico desportivo à de licenciado alargava a formação de um e de outro. Mas em vez de efetivamente agregar conhecimento pedagógico à formação do técnico desportivo, e assim dar maior equilíbrio à formação docente, este movimento de anexação acabou impulsionando o processo que viria a conhecido como "desportivização" da formação dos professores de EF escolar ${ }^{22}$. Um processo que viria a se reforçar ainda mais com a promulgação da Lei n. 5692/1971 (LDB), e do Decreto n. 69.450/1971, nos quais a EF era tratada como uma atividade escolar destinada ao desenvolvimento da aptidão física. Os apelos em prol da prática esportiva e de uma condição física mais saudável ${ }^{23}$ levaram a formação em EF, mesmo sob a insígnia da licenciatura, cada vez mais para fora dos muros da escola. Curiosamente, a anexação da formação do técnico a do licenciado em EF naquele

\footnotetext{
${ }^{22}$ Para saber mais sobre o processo de desportivização na EF brasileira, consultar Bracht (1997).

${ }^{23}$ Para se ter uma noção dos pressupostos referentes à aptidão física e saúde e a relação com o estilo de vida, ver FRAGA, Alex B. Exercício da informação: governo dos corpos no mercado da vida ativa. Campinas: Autores Associados, 2006.
} 
momento acabou colaborando para o gradativo distanciamento entre os que atuavam dentro e os que atuavam fora da escola, o que provavelmente acabou reforçando os argumentos em prol de uma nova divisão entre as habilitações.

Além dos atos normativos que vieram na esteira da Reforma Universitária de 1968, o processo de federalização da ESEF também repercutiu fortemente na composição da grade curricular do curso de EF daquele período. Com a incorporação da Escola à estrutura da UFRGS, algumas disciplinas passaram a ser ministradas por outras unidades, novas disciplinas passaram a compor o currículo, o curso passou a ser organizado em semestres e, com a obrigatoriedade da EF para todos os cursos de graduação (definida pelo Decreto-Lei n. 705/ 1969), a ESEF passou a oferecer disciplinas para toda a Universidade. AEF passa a ser componente curricular transversal no ensino superior, mesmo que de forma pouco articulada com os projetos pedagógicos dos demais cursos.

No primeiro semestre de 1987 o curso superior de EF da ESEF passa por mais uma grande reformulação curricular. No mesmo ano, 16 de junho, o CFE homologava a Resolução n. 3/1987. Entre tantos pontos, esta resolução previa a ampliação da carga horária de 1800 para 2800 horas, concedia maior autonomia às IES na formulação dos projetos curriculares e, a questão mais emblemática, instituía a divisão do curso de EF em bacharelado e licenciatura ${ }^{24}$ (AZEVEDO; MALINA, 2004, SOUZA NETO et. al., 2004, BENITES; SOUZA NETO; HUNGER, 2008).

A reformulação curricular do curso de EF da ESEF daquele ano foi baseada em discussões acumuladas pela comunidade esefiana desde, pelo menos, o início da década de $1980^{25}$. Tamanho envolvimento possibilitou que a ESEF incorporasse a discussão da época sobre os rumos da formação dentro e fora da escola. Da Resolução n. 3/1987,

\footnotetext{
${ }^{24}$ Acerca deste processo de divisão da graduação em EF em Bacharelado e Licenciatura, consultar o artigo da Comissão de Especialistas da SESu/MEC publicado na Revista Brasileira de Ciências do Esporte, v. 18, n. 3, maio de 1997, p 247-256.

${ }^{25}$ Este movimento da comunidade esefiana de certo modo repercutia o movimento da área no Brasil entre o final dos 1970 e início dos 1980, que acabou desembocando na Resolução n. 03/ 1987 (AZEVEDO; MALINA, 2004)
} 
um dos requisitos atendidos foi o aumento da carga horária, que levou o curso de três para quatros anos, distribuídos em oito semestres letivos, e causou um impacto considerável na estrutura da grade e na infraestrutura da escola nos primeiros anos após a implantação. Mas a tomada de decisão mais importante para os futuros movimentos curriculares da ESEF foi outra: a manutenção da oferta de umúnico curso de licenciatura, apesar da possibilidade de abertura do bacharelado.

A previsão de tal possibilidade na Resolução n. 03/1987 levou algumas IES do centro do país, especialmente as estaduais de São Paulo $^{26}$, a criar os cursos de bacharelado com a intenção explícita de adequar os currículos à formação técnico-científica demandada pelo mercado de trabalho fora da escola e a intenção implícita de "descontaminar" os currículos das discussões pedagógicas fundamentais para a EF escolar ${ }^{27}$.

A ESEF, por sua vez, resolve bancar a licenciatura de caráter mais generalista, abarcando em uma única habilitação o que a Resolução n. 03/1987 previa em duas. É bem possível que a divisão da formação em duas habilitações tenha sido aventada durante esse processo de reformulação, pois os primeiros argumentos em prol da divisão do curso já vinham sendo "aprimorados" desde homologação da Resolução n. 69/1969, como abordamos anteriormente, mas não era uma posição dominante na Escola. Apesar de a decisão da comunidade esefiana naquele momento ter sido pela efetivação da chamada "licenciatura ampliada"28, a relação de forças entre o conhecimento relativo à educação escolar nessa configuração mais ampla, assim como já

\footnotetext{
${ }^{26} \mathrm{Os}$ argumentos que levaram algumas instituições paulistas a criarem o bacharelado podem ser encontrados no artigo Educação Física na UNESP de Rio Claro: Bacharelado e Licenciatura, de José Maria de Camargo Barros, publicado na Revista Motriz em 1995.

${ }^{27} \mathrm{O}$ trecho a seguir, extraído do artigo de Barros (1995, p. 71), ilustra bem tais intenções: "até 1987 todos os cursos de Graduação em Educação Física, diríamos, vestiam uma camisa de força imposta pelo CFE, que restringia as suas possibilidades ao oferecimento do curso de licenciatura, e complementarmente, o de Técnico Esportivo".

${ }^{28}$ "Licenciatura ampliada" foi o termo empregado pelo campo da EF para se referir aos currículos de licenciatura que reuniam em único curso o que a Resolução n. 03/1987 previa em dois: bacharelado juntamente com licenciatura (SOUZA NETO et. al., 2004). Não confundir com "licenciatura plena", que se refere à formação de docentes para a educação básica em nível superior em todas as áreas, que na Lei n. 5692/1971 foi usada para se diferenciar da "licenciatura curta", com duração menor e certificação específica para atuação no ensino de primeiro grau. Portanto, o termo "licenciatura ampliada" só faz sentido no contexto específico da EF. Para as demais áreas soa redundante.
} 
havia ocorrido quando da incorporação da formação de técnico desportivo a do licenciado na Resolução n. 69/1969, gradativamente foi pendendo para o lado de fora da escola.

Além das questões macroestruturais desencadeadas pela opção da licenciatura ampliada, a reformulação curricular de 1987 provocou uma mudança na "cultura de matrículas" nas disciplinas do curso de EF da ESEF, pois concedeu aos alunos um rol de disciplinas de caráter eletivo, deixando a critério de cada um a definição dos percursos que queriam trilhar. Antes da implantação da licenciatura ampliada praticamente todos os estudantes da ESEF trilhavam o mesmo percurso acadêmico durante a graduação ${ }^{29}$. Depois de 1987 o cenário muda radicalmente. O número de disciplinas eletivas se "hipertrofia" e o quadro se inverte ${ }^{30}$ : para colar grau o estudante precisava cumprir 74 créditos obrigatórios e 117 eletivos. Essa configuração gerava uma situação inusitada: todos obtinham a mesma titulação, mas poucos percorriam a mesma trajetória curricular. De 1987 para cá a relação entre obrigatórias e eletivas variou; em alguns momentos ficou mais equilibrada, em outros menos, mas a cultura curricular eletiva permaneceu na reformulação seguinte.

Em 2004 a comunidade esefiana promoveu mais uma grande reformulação curricular. E dessa vez, diferentemente do que ocorrera em 1987, o curso de EF foi dividido em duas habilitações: bacharelado e licenciatura, que passaram a funcionar plenamente em 2005. Depois de muito tempo sustentando a formação em EF em única nomenclatura, a ESEF acabou se inclinando mais fortemente em favor da divisão quando foi homologada a Resolução n. 7/2004 da Câmara de Educação Superior do Conselho Nacional de Educação (CNE), de 31 de março de 2004, que instituiu as Diretrizes Curriculares para os cursos de graduação em $\mathrm{EF}^{31}$.

\footnotetext{
${ }^{29} \mathrm{As}$ diferenças de percurso no período anterior a 1987 se restringiam as duas disciplinas eletivas incluídas em decorrência da Resolução n. 69/1969 e aos mecanismos de distinção de percursos para homens e mulheres.

${ }^{30}$ Este foi outro ponto de tensão prospectado na pesquisa empírica, mas que não pode ser tratado aqui em função dos limites estipulados para cada artigo neste número especial.

${ }^{31} \mathrm{E}$ importante ressaltar que o termo "bacharelado" não consta nesta resolução, mas sim "graduado" e "licenciado". Mais detalhes sobre o processo de construção destas diretrizes podem ser encontrados em Frizzo (2010).
} 
As justificativas apresentadas para a divisão do curso eram muito similares àquelas que haviam sido rechaçadas na reformulação de 1987, só que desta vez ganharam mais intensidade em função das modificações no campo decorrentes da regulamentação da profissão de EF, ocorrida em $1^{\circ}$ de setembro de 1998 através da promulgação da Lei n. 9696/1998 ${ }^{32}$, que institui a figura do profissional de EF. Além dos efeitos produzidos pela regulamentação no campo de atuação, a homologação das Resoluções n. 1 e n. 2/2002 do CNE, que instituía as Diretrizes Curriculares Nacionais para a Formação de Professores de Educação Básica, também contribuiu para que o movimento pró-bacharelado dentro da ESEF ganhasse ainda mais força. Essas resoluções estabeleceram de maneira contundente os contornos da formação de professores efetivamente voltada para a Escola Básica desde o início da graduação, não dando margem para a existência de cursos de licenciatura nos quais o ofício docente fosse apenas um adendo no último semestre sob a forma de estágio escolar, tal como ocorria com a licenciatura ampliada na ESEF.

Para dar conta de sistematizar tantas mudanças, a UFRGS instituiu a Coordenadoria de Licenciaturas (COORLICEN), com o objetivo de propor uma reformulação unificada para todos os cursos de licenciatura da Universidade, e com previsão de implantação conjunta estipulada para 2005. Entre 2002 e 2003, com a "nova

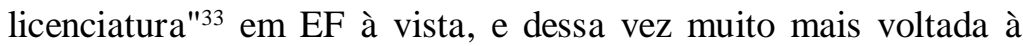
formação de professores desde os primeiros semestres, a Comissão de Graduação da ESEF (COMGRAD) ${ }^{34}$ iniciou os estudos para a criação do bacharelado. A idéia era estruturar um currículo capaz de sustentar tanto a formação do profissional de EF para o mercado de trabalho, quanto preparar o pesquisador iniciante na área das

\footnotetext{
${ }^{32} \mathrm{~A}$ promulgação da lei vem gerando muitos embates políticos no campo acadêmico profissional da EF, e ultimamente tem acirrado os ânimos entre licenciados e bacharéis formados no período posterior depois de 2004. Para uma maior noção mais aprofundada dos embates prós e contras a regulamentação, consultar o site Conselho Federal de Educação Física (CONFEF) (Disponível em: <http://www.confef.org.br>. Acesso em: 24 nov. 2010) e o site do Movimento Nacional Contra a Regulamentação do Profissional de Educação Física (MNCR) (Disponível em: <http://mncref.sites.uol.com.br>. Acesso em: 25 nov. 2010).

${ }^{33}$ Termo consagrado pela comunidade esefiana para se referir ao curso de licenciatura que substitui a licenciatura que se encontra em extinção.

${ }^{34}$ Conforme Ata de no. 08 da Comissão de Graduação da ESEF/UFRGS.
} 
ciências do movimento humano ${ }^{35}$. A homologação da Resolução n. 7/2004 do CNE/CES acabou precipitando todo o processo, levando a COMGRAD a apresentar, e o CONSUNI a aprovar, ambas as propostas ainda em 2004 com previsão de início em 2005.

É notória a diferença entre o processo de implantação da licenciatura ampliada em 1987 e a implantação do bacharelado/ licenciatura em 2005. Enquanto no primeiro caso a comunidade esefiana passou quase dez anos discutindo a estrutura curricular mais adequada ao perfil do egresso estipulado, o segundo caso não chegou a completar dois anos de discussão, o que levou a formulação de currículos sem um amplo respaldo interno; muito preso aos textos das diretrizes e com uma estrutura praticamente idêntica a da licenciatura ampliada vigente até então. Esta "semelhança" chegou a ser utilizada como um dos argumentos de convencimento para a aceitação da proposta, mas ao contrário do que se poderia supor, apontava-se mais similaridades entre o currículo da "antiga licenciatura" (em extinção) e a estrutura prevista pela Resolução n. 7/2004 do CNE/CES para a formação do graduado em EF (bacharelado) do que para a formação do licenciado em EF. É interessante destacar que sob a insígnia da licenciatura ampliada os conhecimentos relativos à formação de professores, assim como ocorrera com a incorporação da formação do técnico desportivo a do licenciado em EF na Resolução n. 69/1969, foram gradativamente relegados a um segundo plano; subsumiram em meio às disciplinas de cunho desportivo ou biomédico.

$\mathrm{Na}$ análise que fizemos das grades curriculares foi possível identificar que o currículo da licenciatura em extinção funcionou como uma "plataforma de montagem" dos currículos da "nova licenciatura" e do bacharelado na ESEF. Aestrutura interna da maioria das disciplinas oferecidas para os novos cursos praticamente não foi alterada, apenas redistribuída nos dois percursos curriculares. Em alguns casos uma mesma disciplina muda apenas de categoria

\footnotetext{
${ }^{35}$ É importante lembrar que esta preocupação ficou mais evidente com a implantação do mestrado em 1989 e do doutorado em 2000.
} 
quando aparece em uma grade ou em outra: obrigatória para um curso, eletiva para outro. Há outras diferenças no "corpo" do currículo, por exemplo, a grande maioria das disciplinas obrigatórias oferecidas à licenciatura em EF pelos departamentos vinculados à Faculdade de Educação (FACED) não aparece para o bacharelado. Mas a maior alteração está nos estágios obrigatórios ao final do curso. Para a "nova licenciatura" há previsão de 450 horas distribuídas nos três níveis de ensino: infantil, fundamental e médio ${ }^{36}$. Para o bacharelado também são previstas 450 horas, mas divididas conforme o campo de intervenção profissional: atividades esportivas, atividades físicas e saúde e atividades recreativas e lazer. A equivalência entre as cargas horárias dos estágios nos projetos pedagógicos dos dois cursos foi uma decisão da ESEF, já que as respectivas diretrizes exigiam 400 horas para o licenciado e 300 horas para o graduado em EF.

Não há dúvidas de que a plataforma curricular da licenciatura ampliada de 1987 foi construída sobre um longo e sólido processo de discussão sobre os rumos da formação na ESEF daquele período. Tal consistência permitiu que o currículo atravessasse mais de uma década sem grandes questionamentos, contando apenas com ajustes pontuais ao longo do caminho. Mas quando surgiram as diretrizes curriculares em 2004, aquela "velha" plataforma não suportava mais nem mesmo o próprio currículo que sobre ela havia sido construído, portanto, não era difícil imaginar que não suportaria por muito tempo o peso de dois currículos. Os sinais do desgaste não demoraram a aparecer; e já em 2007 a comunidade esefiana começava a colocar em pauta o atual ordenamento curricular. De lá para cá os debates se tornaram cada vez mais intensos, muitos deles protagonizados pelo movimento estudantil, proporcionando um lastro de discussões considerável para a reformulação curricular que ora se avizinha.

\footnotetext{
${ }^{36}$ Para mais informações sobre as alterações nos estágios obrigatórios consultar: Os estágios de docência e a formação de professores em educação física: um estudo de caso no curso de licenciatura da EsEF/UFRGS (NUNES, 2010).
} 


\section{ConsideraÇões Finals}

Analisar em um artigo científico os 70 anos de história curricular da ESEF é um risco. O período é muito longo, o material empírico é imenso, a literatura é volumosa, os pontos de vista são incontáveis e as conclusões invariavelmente parciais. Para dar conta desta empreitada com certa margem de segurança, tivemos de traçar estratégias, demarcar o percurso, revisar rotas e, principalmente, estabelecer recortes que nos permitissem de algum modo finalizar uma investigação que a princípio parecia não ter mais fim.

Começamos mapeando os cursos de formação superior oferecidos pela escola através das grades curriculares de todo o período. A grande maioria não estava disponível na íntegra, o que nos obrigou a buscar no acervo do CEME fontes alternativas, tais como os registros de graus, para de algum modo visualizar o currículo percorrido pelos alunos daquele tempo. Mesmo assim não conseguimos remontar as grades dos anos de 1958, 1959 e entre os anos de 1963 e 1972.

A partir do que nos foi possível recompor, passamos a mapear os períodos em que as alterações nas grades eram mais notórias. Em seguida, procuramos estabelecer as correlações entre aquelas temporalmente mais próximas e em seguida entre aquelas mais distantes. Por conveniência, agrupamos essas alterações em seis grandes tópicos e passamos a chamá-los de "pontos de tensão", pois percebemos que eles não apenas se constituíram a partir de alterações curriculares importantes, mas também as mobilizaram.

Os pontos de tensão foram compostos em função do nível de articulação interna e do grau de intensidade com que afetaram a estrutura curricular da ESEF ao longo destes anos: uns mais, outros menos. E como não era possível examinar um por um, nós optamos por aquele que perpassava todo o período analisado e se articulava mais densamente com os demais: relação entre os diferentes cursos de formação superior em EF oferecidos pela ESEF e os atos normativos educacionais correspondentes. 
Ao examinarmos este ponto nos foi possível perceber que a pressão exercida pelo marco regulatório educacional sobre os cursos de formação da ESEF foi mais intensa em três grandes momentos: federalização da Escola em 1970, mudanças curriculares de 1987 e divisão licenciatura/bacharelado em 2005. Cada um deles com características próprias de seu tempo, mas permeados por alguns elementos comuns referentes às disputas pela validação do conhecimento dentro da área.

De um modo geral, o processo de federalização da ESEF se deu na esteira do processo de implantação da Reforma Universitária, acontecimentos que causaram modificações estruturais muito profundas em toda a Escola. De modo mais específico, a homologação da Resolução n. 69/1969 também gerou alterações na disposição da grade curricular da ESEF. Entre tantas medidas, determinava a incorporação da formação do técnico desportivo à do licenciado. Um movimento de anexação que alargava a formação em nível superior e colocava em destaque os conhecimentos de cunho didático-pedagógico voltados para o ambiente escolar.

Em 1987, com a Resolução n. 3/1987 do CFE, foi aberta a possibilidade de separação da formação em cursos de bacharelado e licenciatura EF, com o objetivo de atender as demandas de um campo de trabalho em franca expansão fora da escola. A comunidade esefiana, diferentemente do que ocorrera em universidades no centro do país, decide manter uma formação mais generalista com a proposição da "licenciatura ampliada". Apesar de a decisão ter sido em favor da formação de cunho mais didático-pedagógico, a relação de forças entre o conhecimento relativo à educação escolar nessa configuração ampliada, ao contrário do que se poderia supor, gradativamente foi pendendo para o lado de fora da escola.

Em 2004, sob influência das novas diretrizes curriculares para os cursos de graduação em EF (Resolução n. 7/2004 do CNE/CES) e para a formação de professores de Educação Básica (Resoluções n. 1 e n. 2/2002 do CNE), a ESEF decide criar o bacharelado e reformular a licenciatura. Os argumentos anteriormente rechaçados em 1987 pela comunidade esefiana voltam com força nesse 
momento, embalados pela promulgação da Lei n. 9696/1998 que instituiu a regulamentação da profissão. A licenciatura ampliada, depois de quase 20 anos, entrou em regime de extinção na ESEF, mas a plataforma curricular que a sustentava seguiu sustentando os dois novos cursos. Bem pouco tempo depois, começaram a aparecer as primeiras "fissuras" nas grades da "nova licenciatura" e do bacharelado.

Em 2010, depois de uma série de debates protagonizados pelo movimento estudantil (FILIPPINI; DIEHL; FRIZZO, 2010), o CONSUNI da ESEF aprovou os princípios gerais contidos na carta elaborada pela comissão de reestruturação curricular, desencadeando um novo processo de reconstrução curricular, prevendo a dupla modalidade de formação (licenciatura/bacharelado) em um curso único de EF.

Trata-se de um movimento relativamente novo dentro do contexto da formação em EF, mas mobilizado por um elemento comum aos processos de reformulação anteriores: disputas no campo de atuação profissional entre as "tribos" ${ }^{37}$ da EF escolar e as "tribos" de fora da escola pela validação do conhecimento que lhes compete: licenciado versus bacharel ou professor versus profissional. Um conflito fratricida que se alimenta da divisão da formação mas não necessariamente se apazigua com a simples unificação do curso.

Diferentemente do que ocorreu com a maioria dos processos de reformulações anteriores, neste a ESEF não está sendo pressionada a mudar em função de uma legislação educacional específica. A mobilização emana, principalmente, da inconformidade de boa parte da comunidade esefiana com a estrutura curricular vigente e com a discriminação das habilitações para o exercício profissional imposta pela Lei n. 9696/1998 que regulamentou a profissão de EF.

Certamente não será fácil, como nunca foi na história da ESEF, produzir um currículo que contemple as peculiaridades de nosso

\footnotetext{
${ }^{37}$ Expressão cunhada por Hugo Lovisolo (2000) para se referir aos diferentes grupos que habitam a área da EF.
} 
tempo, prepare as futuras gerações para enfrentar as mutações no mundo do trabalho e preserve a tradição da Escola. Mas o lastro de discussões já produzido, independentemente das posições contrárias ou favoráveis à divisão bacharelado/licenciatura, não deixa dúvidas sobre a necessidade de se abandonar a "velha" plataforma curricular que vem sustentado os currículos da ESEF nos últimos 20 anos. E isto, por si só, nos faz pensar que o processo vivido pela Escola na primeira década do século XXI, apesar de turbulento, pode não ter sido tão ruim quanto supúnhamos. 
Changes in the curriculum of a septuagenarian school: a study on the frameworks of higher education courses in Physical education of the ESEF/UFRGS

Abstract: This article is based on a study about the Physical Education Curricula for Higher Education at ESEF/UFRGS University in its 70 years of existence. The general goal was to show elements that rendered important curricular changes through this time. Therefore, we made a mapping of the curricular grids from 1941 to 2010 based on the following documents: records of degrees, registration books, courses' catalogues, UFRGS's website among others. From the documental analyses, we highlight six points of tension which were constituted from, and at the same time rendered important curricular changes: (1) the ESEF's Curricula and the educational regulatory mark; (2) the linking of disciplines to different departments; (3) the separation of the curricular paths of men and women; (4) the proportion between mandatory and elective disciplines; (5) the emergence and expansion of mandatory teaching practice; (6) the strengthening of research at the initial formation. In this article, we focused on the first point because it covers all studied period and deeply report to the others. We concluded that the tension pressed by the educational regulatory mark on ESEF's courses was stronger in 3 major moments: The school's federalization in 1970, the curricular changes in 1987 and the division of the teaching course/baccalaureate in 2005.

Key Words: Physical Education. Curriculum. Professional Formation. 
Alteraciones curriculares de una escuela septuagenaria: un estudio sobre los mapas curriculares de los cursos de formación superior en Educación Física de ESEF/UFRGS

Resumen: El artículo es resultado de un estudio sobre los currículos de formación superior en Educación Física de ESEF/UFRGS en 70 años de existencia. El objetivo general fue destacar elementos que provocaron alteraciones curriculares importantes en el transcurso de este período. Para ello, realizamos un mapeo de los mapas curriculares de 1941 a 2010 por medio de los siguientes documentos: registros de niveles, catálogos de cursos, página de UFRGS en Internet entre otros. A través del análisis documental destacamos seis "puntos de tensión" que se presentaron a partir de y al mismo tiempo movilizaron importantes alteraciones curriculares: 1) currículos de ESEF y el marco regulatorio educativo 2) vinculación de las asignaturas a los diferentes departamentos; 3) separación de los recorridos curriculares de hombres y mujeres; 4) proporcionalidad entre asignaturas obligatorias y selectivas; 5) surgimiento y expansión de las prácticas obligatorias; 6 ) fortalecimiento de la investigación en la formación inicial. Por cubrir todo el período analizado y articularse de forma más densa con los demás, nos concentramos aquí exclusivamente en el primer punto. Concluimos que la presión ejercida por el marco regulatorio educativo sobre los cursos de formación de ESEF/UFRGS fue más intensa en tres grandes momentos: federalización de la escuela en 1970, cambios curriculares en 1987 y división licenciatura/diplomatura el 2005.

Palabras Clave: Educación Física. Currículo. Formación Profesional. 


\section{REFERÊNCIAS}

AZEVEDO; MALINA, Memória do currículo de formação profissional em educação física no Brasil. Revista Brasileira de Ciências do Esporte, Campinas, v. 25, n. 2, p. 129-142, jan. 2004.

BARROS, José Maria de Camargo. Educação Física na UNESP de Rio Claro: bacharelado e licenciatura. Motriz, Rio Claro, v. 1, n. 1, p. 71-80, jun. 1995.

BENITES, Larissa Cerignoni; SOUZANETO, Samuel de; HUNGER, Dagmar Aparecida Cynthia França. O processo de constituição histórica das diretrizes curriculares na formação de professores de Educação Física. Educação e Pesquisa (USP), São Paulo, v. 34, p. 343-360, maio/ago. 2008.

BRACHT, Valter. Sociologia crítica do esporte: uma introdução. Vitória: UFES, 1997.

BRASIL. [Constituição, 1937]. Constituição dos Estados Unidos do Brasil, de 10 de novembro de 1937. Disponível em: <http://www.planalto.gov.br/ccivil_03/ constituicao/constitui\%C3\%A7ao37.htm>. Acesso em: 15 nov. 2010.

BRASIL. Lei n. 1.153/1950, de 04 de julho de 1950 - Estende a alunos do Curso Normal de Educação Física regalias conferidas aos licenciados em Educação Física, de que trata o Decreto-Lei no 1.212, de 17 de abril de 1939. 1950. Disponível em: <http://www2.camara.gov.br/legin/fed/lei/1950-1959/lei-1153-4-julho-1950363453-publicacao-1-pl.html>. Acesso em: 12 dez. 2010.

Lei n. 4.024/1961, de 20 de dezembro de 1961. Fixa as Diretrizes e Bases da Educação Nacional. 1961. Disponível em: <http://www.planalto.gov.br/ccivil_03/ Leis/L4024.htm>. Acesso em: 18 dez. 2010.

Lei n. 5.540/1968, de 28 de novembro de 1968. Fixa normas de organização e funcionamento do ensino superior e sua articulação com a escola média, e dá outras providências. 1968b. Disponível em: <http://www.planalto.gov.br/ ccivil_03/Leis/L5540.htm>. Acesso em: 25 nov. 2010.

Lei n. 5.692/1971, de 11 de agosto de 1971. Fixa diretrizes e bases para o ensino de $1^{\circ}$ e $2^{\circ}$ graus, e dá outras providências. 1971a. Disponível em: <http:/ /www.pedagogiaemfoco.pro.br/5692_71.htm>. Acesso em: 12 nov. 2010.

Lei n. 9.696/1998, de 01 de setembro de 1998. Dispõe sobre a regulamentação da profissão de Educação Física e cria os respectivos conselho federal e conselhos regionais de educação física. Brasília, 1998. Disponível em: <http://www.planalto.gov.br/ccivil_03/Leis/L9696.htm>. Acesso em: 24 nov. 2010.

BRASIL. Conselho Federal de Educação. Decreto-Lei n. 1.212/1939, de 17 de abril de 1939. Cria, na Universidade do Brasil, a Escola Nacional de Educação Física e Desportos. 1939. Disponível em: <http://www2.camara.gov.br/legin/fed/ declei/1930-1939/decreto-lei-1212-17-abril-1939-349332-retificacao-72183pe.html>. Acesso em: 16 set. 2010. 
Decreto n. 7.219/1941, de 27 de maio de 1941. Concede autorização para o funcionamento da Escola Superior de Educação Física do Estado do Rio Grande do Sul. 1941. Disponível em: <http://cev.org.br/biblioteca/compilacaolegislacao-educacao-fisica-desportos>. Acesso em: 12 dez. 2010.

Decreto n. 15.582/1944, de 16 de maio de 1944. Concede reconhecimento a diversos cursos da Escola Superior de Educação Física de Porto Alegre. 1944. Disponível em: <http://cev.org.br/biblioteca/compilacao-legislacao-educacao-fisicadesportos>. Acesso em: 12 dez. 2010.

. Decreto-Lei n. 8.270/1945, de 03 de dezembro de 1945. Altera disposições do Decreto-Lei número 1.212, de 17 de abril de 1939. 1945. Disponível em: <http:/ /www.fiscolex.com.br/doc_107076_DECRETO_LEI_N_8_270_3_ DEZEMBRO_1945.aspx >. Acesso em: 16 set. 2010.

Decreto-Lei n. 53/1966, de 18 de novembro de 1966 . Fixa princípios e normas de organização para as universidades federais e dá outras providências. 1966. Disponível em: <http://www.jusbrasil.com.br/legislacao/126183/decreto-lei53-66>. Acesso em: 18 dez. 2010.

Decreto-Lei n. 252/1967, de 28 de fevereiro de 1967. Estabelece normas complementares ao decreto-lei ํㅜ 53, de 18 de novembro de 1966, e dá outras providências. 1967. Disponível em: <http://www6.senado.gov.br/legislacao/ ListaPublicacoes.action?id=117229 >. Acesso em: 24 nov. 2010.

Decreto-Lei n. 62.997/1968, de 16 de julho de 1968. Aprova o Plano de Reestruturação da Universidade Federal do Rio Grande do Sul. 1968a. Disponível em: <http://www2.camara.gov.br/legin/fed/decret/1960-1969/decreto-62997-16julho-1968-404329-publicacaooriginal-1-pe.html>. Acesso em: 20 dez. 2010.

Decreto-Lei n. 705/1969, de 25 de julho de 1969. Altera a redação do artigo 22 da Lei n. 4.024, de 20-12-61, estendendo a obrigatoriedade da prática da Educação Física a todos os níveis e ramos de ensino. 1969e. Disponível em: <http:/ /cev.org.br/biblioteca/compilacao-legislacao-educacao-fisica-desportos>. Acesso: em 12 dez. 2010.

Resolução n. 9/1969, de 10 de outubro de 1969. Fixa os mínimos de conteúdo e duração a serem destinados à formação pedagógica nos cursos de licenciatura. 1969d. Disponível em: <http://cev.org.br/biblioteca/compilacaolegislacao-educacao-fisica-desportos>. Acesso: em 12 dez. 2010.

Resolução n. 69/1969, de 06 de novembro de 1969. Fixa os mínimos de conteúdo e duração a serem observados na organização dos Cursos de Educação Física. 1969a. Disponível em: <http://www.efdeportes.com/efd141/formacaoprofissional-em-educacao-fisica.htm>. Acesso em: 24 nov. 2010.

Parecer n. 894/1969, de 14 de novembro de 1969. Fixa o currículo mínimo, a duração e a estrutura dos cursos superiores de graduação em Educação Física. 1969b. Disponível em: < http://www.scielo.br/pdf/ep/v34n2/09.pdf>. Acesso em: 26 nov. 2010. 
Decreto n. 69.450/1971, de 01 de novembro de 1971. Regulamenta o artigo 22 da Lei número 4.024, de 20 de dezembro de 1961, e alínea c do artigo 40 da Lei 5.540, de 28 de novembro de 1968 e dá outras providências. 1971b. Disponível em: <http://www.planalto.gov.br/ccivil_03/decreto/D69450.htm>. Acesso em: 25 nov. 2010.

Resolução n. 03/1987, de 16 de junho de 1987. Fixa os mínimos de conteúdo e duração a serem observados nos cursos de graduação em Educação Física (Bacharelado e/ou Licenciatura Plena). 1987. Disponível em: <http:// www.ufpb.br/sods/consepe/resolu/1990/Res0387-cfe.htm>. Acesso em: 16 set. 2010.

BRASIL. Conselho Nacional de Educação. Câmara de Educação Superior. Resolução n. 7/2004, de 31 de março de 2004, que instituiu as Diretrizes Curriculares para os cursos de graduação em EF. 2004. Disponível em: <http:// portal.mec.gov.br/index.php? option=com_content \&view=article\&id=12991 >. Acesso em: $18 \mathrm{dez} .2010$.

BRASIL. Conselho Nacional de Educação. Conselho Pleno. Resolução CNE/CP n. 1/2002, de 18 de fevereiro de 2002. Institui Diretrizes Curriculares Nacionais para a Formação de Professores da Educação Básica, em nível superior, curso de licenciatura, de graduação plena. 2002a. Disponível em: <http://portal.mec.gov.br/ cne/arquivos/pdf/CP012002.pdf>. Acesso em: 24 nov. 2010.

Resolução CNE/CP n. 2/2002, de 19 de fevereiro de 2002. Institui a duração e a carga horária dos cursos de licenciatura, de graduação plena, de formação de professores da Educação Básica em nível superior. 2002b. Disponível em: <http://portal.mec.gov.br/cne/arquivos/pdf/CP022002.pdf>. Acesso em: 24 nov. 2010.

BRASIL. Ministério do Esporte. Centros de Desenvolvimento de Esporte Recreativo e de Lazer (CEDES). Disponível em: <http://www.esporte.gov.br/ sndel/esporteLazer/cedes/apresentacao.jsp>. Acesso em: $21 \mathrm{dez} .2010$.

BRAUNER, Vera Lúcia Pereira. La formación del profesorado de Educación Física em la UFRGS, Porto Alegre (Brasil): tendências teóricas. 1999. Tese (Doutorado) - Educació Social Contemporánea, Universitat de Barcelona, Barcelona, 1999. Disponível em: <http://www.bibliotecadigital.ufrgs.br/da.php?nrb= $000280491 \& \mid \mathrm{loc}=2010 \& \mathrm{I}=802$ ceee14f59dcc6 $>$. Acesso em: 19 ago. 2010.

BRUGNEROTTO, Fábio; SIMÕES, Regina. Caracterização dos currículos de formação profissional em Educação Física: um enfoque sobre saúde. Physis: Revista de Saúde Coletiva, Rio de Janeiro, v. 19, n. 1, p. 149-172, 2009.

COMISSÃO DE ESPECIALISTASDE ENSINO DE EDUCAÇÃO FÍSICA DASESU/MEC. Descrição de área Formação Profissional em Educação Física. Revista Brasileira de Ciências do Esporte, v. 18, n. 3, p 247-256, maio 1997. 
FILIPPINI, Isabella; DIEHL, Vera Regina Oliveira; FRIZZO, Giovani Felipe. Formação de professores de Educação Física da ESEF/UFRGS: balanço após cinco anos da divisão do curso. Revista Digital EF Deportes, Buenos Aires, v. 15, n. 144, maio 2010. Disponível em: <http://www.efdeportes.com/efd144/formacao-deprofessores-de-educacao-fisica.htm> Acesso em: 1 nov. 2010.

FRAGA, Alex B. Exercício da informação: governo dos corpos no mercado da vida ativa. Campinas: Autores Associados, 2006.

FRIZZO, Giovanni. Divisão da formação em educação física: "crônica de uma morte anunciada". Germinal: Marxismo e Educação em Debate, Londrina, v. 2, n. 2, p. 163-173; ago. 2010.

FUZII, Fábio Tomio; SOUZA NETO, Samuel de; BENITES, Larissa Cerignoni. Teoria da formação e avaliação no currículo de Educação Física. Motriz, Rio Claro, v. 15, n. 1, jan./mar. 2009

GOELLNER, Silvana Villodre et. al. ESEF 65 anos: entre memórias e histórias. Movimento, Porto Alegre, v. 11, n. 3, p. 201-218, set./dez. 2005.

GUTIERREZ, Washington. ESEF: história. Porto Alegre: ESEF/UFRGS, 1971. Disponível em: <http://www.esef.ufrgs.br/historia.htm> Acesso em: 10 nov. 2010.

LOVISOLO, Hugo R. Atividade física, educação e saúde. Rio de Janeiro: Sprint, 2000.

MAZO, Janice Zarpellon. Memórias da Escola Superior de Educação Física da Universidade Federal de Educação Física (ESEF/UFRGS): um estudo do período de sua fundação até a federalização (1940-1969). Movimento, Porto Alegre, v. 11, n. 1, p.143-167, jan./abr. 2005.

MENDES, Cláudio Lúcio. O campo do currículo e a produção curricular na educação física nos anos 90. Arquivos em Movimento, Rio de Janeiro, v. 1, n. 2, p. 39-48, jul./dez. 2005.

MENEZES, Ebenezer Takuno de; SANTOS, Thais Helena dos. Currículo (verbete). In: DICIONÁRIO Interativo da Educação Brasileira. São Paulo: Midiamix, 2002, Disponível em: <http://www.educabrasil.com.br/eb/dic/dicionario.asp?id=349>. Acesso em: 19 nov. 2010.

MOREIRA, Antonio Flavio Barbosa. O campo do currículo no Brasil: construção no contexto da ANPED. Cadernos de Pesquisa, São Paulo, n. 117, p. 81-101, nov. 2002.

NUNES, Cássio Felipe T.; MOLINA NETO, Vicente. O processo de federalização da ESEF/UFRGS sob a perspectiva dos professores o estudo de um caso. Movimento, Porto Alegre, v. 11, n. 2, p.167-190, maio/ago. 2005. 
NUNES, Rute Viégas. Os estágios de docência e a formação de professores em educação física: um estudo de caso no curso de licenciatura da EsEF/ UFRGS. 2010. Dissertação (Mestrado em Ciências do Movimento Humano) Universidade Federal do Rio Grande do Sul, Porto Alegre, 2010.

NUNES, Rute Viégas; FRAGA, Alex Branco. "Alinhamento Astral": o estágio docente na formação do licenciado em Educação Física na ESEF/ UFRGS. Pensar à Prática, Goiânia, v. 9, n. 2, p. 297-311, jul/dez. 2006.

OLIVEIRA, Amauri Bássoli de. Análise critica do currículo das disciplinas práticas do curso de educação física da Universidade Estadual de Maringá. Revista da Educação Física da Universidade Estadual de Maringá, Maringá, v. 1, n. 0 , p.17-25, 1989.

OLIVEIRA, Inês. B., AMORIM, Antônio Carlos R. (Org.) Sentidos de currículo: entre linhas teóricas, metodológicas e experiências investigativas. Campinas, SP: FE/UNICAMP; ANPEd, 2006. Disponível em: <http://www.fe.unicamp.br/ gtcurriculoanped/documentos/LivroDigital_Amorim2006.pdf >. Acesso em: 17 nov. 2010.

PROJETO ESEF 70 anos. Porto Alegre: UFRGS, 2010. Disponível em: <http:// www.esef.ufrgs.br/ceme/projetos/esef70anos/equipe.php> Acesso em: $19 \mathrm{dez}$. 2010.

RIO GRANDE DO SUL. ESCOLA SUPERIOR DE EDUCAÇÃO FÍSICA. Registro de Atas de 1940.

Registro de Graus - 1941, 1942.

Registro de Graus - 1943.

Registro de Graus - 1944, 1945.

Registro de Graus - 1949, 1950, 1951.

Registro de Graus - 1951, 1952, 1953.

Registro de Graus - 1953.

Registro de Graus - 1959, 1960, 1961, 1962.

Registro de Graus - 1962.

ROTHEN, José Carlos. Os bastidores da reforma universitária de 1968. Educação \& Sociedade, Campinas, v. 29, n. 103, p. 453-475, maio/ago. 2008.

SACRISTÁN, Gimeno. O currículo: uma reflexão sobre a prática. 3. ed. Porto Alegre: Artmed, 1998.

SILVA, Tomaz Tadeu da. Documentos de identidade: uma introdução às teorias do Currículo. Belo Horizonte: Autêntica, 2001. 
O currículo como fetiche: a poética e a política do texto curricular. Belo Horizonte: Autêntica, 1999.

SOUZA, Francisco J.; SOUZA NETO, Samuel de. A Revista Brasileira de Ciências do Esporte e a formação profissional em Educação Física. Revista Digital EF Deportes, Buenos Aires, v. 11, n. 103, 2006. Disponível em: <http:// www.efdeportes.com/efd103/ciencias-do-esporte.htm>. Acesso em: 17 nov. 2010.

SOUZA NETO, Samuel de; ALEGRE, Atílio de Nardi; HUNGER, Dagmar Aparecida Cynthia França; PEREIRA, Juliana Martins. A formação do profissional de educação física no Brasil: uma história sob a perspectiva da legislação federal no século XX. Revista Brasileira de Ciências do Esporte, Campinas, v. 25, n. 2, p. 113-128, 2004.

TAFFAREL, Celi Nelza Zulke. Análise dos currículos de educação física no Brasil: contribuição ao debate. Revista da Educação Física da Universidade Estadual de Maringá, Maringá, v. 3, n. 1, p. 48-56, 1992.

. Currículo, formação profissional na educação física \& esporte e campos de trabalho em expansão: antagonismos e contradições da prática social. Movimento, Porto Alegre, v. 4, n. 7, 1997.

TERIGI, Flávia. Notas para uma genealogia do currículo escolar. Educação e Realidade, Porto Alegre, v. 1, n. 1, fev 1976. Porto Alegre: Universidade Federal do Rio Grande do Sul, Faculdade de Educação, 1996. p. 159- 186.

TRUSZ, Rodrigo Augusto; NUNES, Alexandre Velly. A evolução dos esportes de combate no currículo do Curso de Educação Física da UFRGS. Movimento, Porto Alegre, v. 13, n. 1, p. 179-204, jan./abr. 2007.

UNIVERSIDADE FEDERAL DO RIO GRANDE DO SUL. Escola de Educação Física. Comissão de Graduação. Ata n.08/2004, p. 1-6, 2004 b.

UNIVERSIDADE FEDERAL DO RIO GRANDE DO SUL. Escola de Educação Física. Comissão de Reestruturação Curricular (CRC). Carta ao Conselho da Unidade (CONSUNI) da Escola de Educação Física/UFRGS. Porto Alegre, 9 de julho de 2010.

ZOTTI, S. A. Currículo (verbete). In: LOMBARDI, J. C.; SAVIANI, D.; NASCIMENTO, M. I. M. Navegando pela História da Educação Brasileira. Campinas/SP: Faculdade de Educação UNICAMP, 2006. Disponível em: <http:// www.histedbr.fae.unicamp.br/navegando/glossario/verb_c_curriculo.htm\#_ftn1> Acesso em: 19 nov. 2010. 
